\title{
The earliest transverse grooved stones of Eurasia: Near Eastern distribution, types and chronology
}

\author{
Irina Usacheva
}

1. Tyumen Scientific Centre of Siberian Branch of the Russian Academy of Sciences, Institute of the problems of Northern development. Malygina 86, Tyumen, 625003, Russia. Email: i.usachova@gmail.com

\begin{abstract}
:
Transverse grooved stones (TGS) believed to be used as shaft straighteners, first made their appearance at Epipalaeolithic sites in the Near East from where they spread to the Mediterranean coasts of Africa and Europe, but mostly to Northern Eurasia (the steppe, forest-steppe, and semi-desert zones). It has been discovered that the spread of TGA has been carried out along different paths. Moreover, grooved stones along each of these transmission routes can be distinguished by their unique decorative and morphological characteristics.

The aim of this paper is to clarify the circumstances and the date of appearance of the first TGS, localization of their initial areas, and identification of their respective decorative and morphological features. This is a necessary condition for identifying the starting points of the subsequent transit carriers of TGS' tradition and tracing the directions of interaction in Eurasia during the end of the Pleistocene - the first half of the Holocene period using TGS as markers.

The initial database was formed on the basis of the scientific publications on the Near East. The following is a presentation of the analytical review of at least 200 grooved stones and 80 sites in their starting area in south-western Asia. The analysis used a systematic approach with emphasis on chronology, environment, petrography, morphology, functional-typological data where such were available, and TGS' decor. But first of all, the study pays attention to the distribution of TGS and their cultural and chronological boundaries in this region. For this purpose, it was performed the mapping of findings in two chronological levels - up to 8000 thousand BCE and after, with the marking of decorated products.

The results enabled us to detect that the geographical spread of grooved artefacts of this type is limited in the Near East to the area of central Anatolia and Fertile Crescent, with a boundary along the desert-steppes. At least three concentrations can be clearly distinguished: the Levant, Zagros Mountains, and Upper Mesopotamia - central Anatolia, where the products are characterized by specific features of decorative and morphological design and in one case (Levant) an additional observed petrographic specificity. Currently, the earliest cases are recorded in Early Natufian contexts in the Levant and in Epipalaeolithic contexts of the Anatolian plateau since the 13th millennium cal BCE. Thus, one can confidently state that the introduction of TGS in the Middle East is generally linked to the Epipalaeolithic sites (Natufian, Harifian, and Western Zarzian) and is definitely associated with hunter-gatherers. The heyday of TGS falls on the PPNA and lasts to the beginning of the early Bronze Age, when they finally disappear.
\end{abstract}

Journal of Lithic Studies (2020) vol. 7, nr. 3, 20 p.

DOI: https://doi.org/10.2218/3094

Published by the School of History, Classics and Archaeology, University of Edinburgh

ISSN: 2055-0472. URL: http://journals.ed.ac.uk/lithicstudies/

Except where otherwise noted, this work is licensed under a CC BY 4.0 licence. 
Keywords: grooved stones; shaft straighteners; "utyuzhki"; ground stone tools; Near Eastern archaeology; Epipalaeolithic; PPNA

\section{Introduction}

A compelling phenomenon of the Stone Age of Eurasia is the category of small stone tools (4-12 cm in length) bearing grooves of a semicircular section that are interpreted as shaft straighteners. These grooved stones (GS) can be divided into two main types (Usacheva 2013a; Wilke \& Quintero 2009: 127-128). The first, considered grooved abraders for wooden shafts of arrows, have longitudinal grooves and are made of abrasive rocks such as sandstones (Oparin \& Tanaino 2015: Table 3). The second type includes artefacts of non-abrasive, heatresistant rocks (steatite, chlorite, talc schist and dense or compact basalt) or ceramic. These are most commonly characterised by transverse grooves. Transverse grooved stones (TGS) or transverse grooved artefacts (TGA) are the most suitable names for this type of product. TGA in northern Eurasia is popularly known as "utyuzhki". The interior of their grooves is most often polished from wear and shows evidence of heating. Some common features, such as the properties of the raw materials, the in-circle diameter of the grooves between 0.7 and $2.1 \mathrm{~cm}$, the environmental contexts of sites, and the use-wear marks indicate that TGS served to straighten cane and reed shafts through heat (e.g., Savage 2014: 182; Solecki \& Solecki 1970; Usacheva 2013a; 2013b). Although these artefacts could have had other additional functions, they were an important tool in the tool kit of a hunter, and as shafts straighteners they were widely spread. This article focuses on the origin of the GS of the second type, their shapes, nature and decoration.

The TGA geographical distribution includes steppes, forest-steppes and semi-deserts of northern-eastern Europe and northern Asia from the territory of the Republic of Moldova to Mongolia and south-western Asia (Usacheva 2016). Analogous finds are recorded on the northern-eastern coast of Africa and in certain areas of southern Europe (Solecki \& Solecki 1970: 836; Stroulia 2010: 18-19). In the New World (Northern and Southern America) and in Southern Africa grooved instruments of this type are recorded both in archaeological and ethnographical contexts (e.g., Solecki \& Solecki 1970: 836-838; Usacheva 2013a: 61-63).

Chronological analyses reveal that TGS originated in south-western Asia before spreading to Africa, southern Europe, eastern Asia and north Eurasia (Usacheva 2006; 2013b: 65-74). The spread was not simultaneous as seen by the distribution of the earliest examples of TGA in northern Eurasia in the form of a chain along the edge of the highlands that separate northern Eurasia from the Near East.

It is nonetheless noteworthy that each TGS area has its own stable decorative and morphological characteristics that allow tracking the propagation of certain traditions over time. Yet this leads to the question of the origins of the spread in south-western Asia? A simple linear algorithm of distribution is not applicable because the intersection of the highlands can be carried out in various ways as it is seen in the example of the Silk Road or network of modern roads. It is therefore more productive to initiate this search through the study of the chronology and different directions of distribution from the standpoint of the decorative and morphological characteristics of Near Eastern TGS.

\section{Distribution, chronology and cultural identity of grooved artefacts}

Research on this question began a decade back with the publication of the monograph "Territories, boundaries and cultures in the Neolithic Near East" (Kozlowski \& Aurenche 2005). The purpose of the authors was to demonstrate through the spread of series of artefacts (170) both the long-standing permanence of cultural borders before and after $8000 \mathrm{cal}$. BCE 
and highlight the less stable zones of contact between cultures. The chronological range of the study comprises the period spanning $10.500 / 10.200$ to $6.400 / 6.200$ cal. BCE, i.e., from PrePottery Neolithic A (PPNA) to the middle Pre-Pottery Neolithic B (PPNB) and onwards (Kozlowski \& Aurenche 2005: 11, 15).

The three maps reflecting the distribution of flat, high and decorated GS, falling globally under the TGS designation, are identified as "shaft straighteners" (Kozlowski \& Aurenche 2005: 24, 158-160, Figs. 2.2.3.1-3). Though the authors of the monograph do not refer shaft straighteners to the category of mass findings, specialists often include them into typical "Neolithic package" of hunter-gatherers (Bar-Yosef 1998: 171, fig. 11; Çilingiroğlu 2005: 34, table 1).

Currently there are at least 80 sites with at least one grooved shaft straightener (Figure 1). The more notable assemblages are nevertheless 12 items at Zavi Chemi Shanidar (Solecki \& Solecki 1970: 832), 19 at Karim Shahir (Howe 1983: 52), seven among the different horizons of Jarmo (Moholy-Nagy 1983: 294), as minimum of 13 at Körtik Tepe (Özkaya \& Coşkun 2011: 123-124, Figs. 26-27, 30), about 50 at Tell Qaramel (Mazurowski \& Kanjou 2012: 215229, Figs. 68-82), and over 100 shaft straighteners and stone plaques at Boncuklu (Baird et al. 2017: 770-772, Figs. 11-13). The cartography of these finds allowed determining the distribution of TGS in the Middle East. The area comprises the Anatolian plateau, mountain valleys and foothills of Upper Mesopotamia, the Levant with the Negev desert in the south and the eastern-western faces of the Zagros Mountains from Upper Mesopotamia almost to the Persian Gulf.

Yet Solecki \& Solecki $(1970: 831,834)$ have pointed out that GS is a new cultural element making its appearance in the Late Epipalaeolithic. Kozlowski and Aurenche (2005: 24 ), in turn, insist that the introduction of grooved artefacts cannot be associated with the Neolithic as they are present among Epipalaeolithic assemblages such as the Natufian, Harifian or western Zarzian. This notion of an early introduction is currently beyond a doubt but the place, date and provenance of this innovation remains unclear. The latest data obtained at a Natufian (el-Wad terrace) site in the Levant where GS is present in all the layers including the lowest (Figure 2: 1-3, 6-8, 10), places the earliest examples no later than 13th millennium cal. BCE (Rosenberg et al. 2012: 99, 112). The radiocarbon analyses on charcoal and bones of ungulates taken from the bottom of the Early Natufian layer has yielded 13 dates within the interval of $14,660-14,030 \mathrm{cal}$. BP $( \pm 1 \sigma)$ (Weinstein-Evron et al. 2012). The radiocarbon dating of Grave 14 at Pınarbaşı (Anatolia) 15,180-14,246 cal. BP $( \pm 2 \sigma)$ containing GS either coincides or predates the Early Natufian (Baird et al. 2013: 183). It is also noteworthy TGS in different layers of the el-Wad terrace contain GS of another type (Rosenberg et al. 2012: Fig. 20, 8; 21, 1, 5, 6), confirming the thesis of a functional and morphological variety of grooved tools.

There is much less data regarding the introduction of TGS in Iraq, north-western Iran and Syria than in south-eastern and central Turkey and the Levant. TGS from the Epipalaeolithic throughout the Protoneolithic cultures of Zagros is recorded in the Zarzian and ShanidarKarim-Shahir Cultures (Figure 3: 1-17, 20). The datings of the Epipalaeolithic layers of Zavi Chemi Shanidar (B) $(10,870 \pm 300 \mathrm{BP})$ and Shanidar (B1) $(10,600 \pm 300 \mathrm{BP})$ (Solecki \& Solecki 1970: 834) respectively yield the calibrated dates of 11,250-10,350 cal. BCE $( \pm 1 \sigma)$ and 11,050-10,150 cal. BCE $( \pm 1 \sigma)$ (calibration performed by I. Usacheva on the basis of Ramsey 2005; Reimer et al. 2004). These represent the earliest radiocarbon dates for TGS in the Zagros area. Meanwhile, the number of TGS at Shanidar-Karim-Shahir sites and a fairly well-developed decor and morphology lead to the assumption that their introduction is associated with the earlier Zarzian Culture where GS findings are rare (Kozlowski \& Aurenche 2005: 24). It is also noteworthy that the Late Zarzian Culture is not only synchronous but has much in common with the early Natufian, where TGS are common (Garrod 1930; Wahida 1981; Olszewski 2012). 


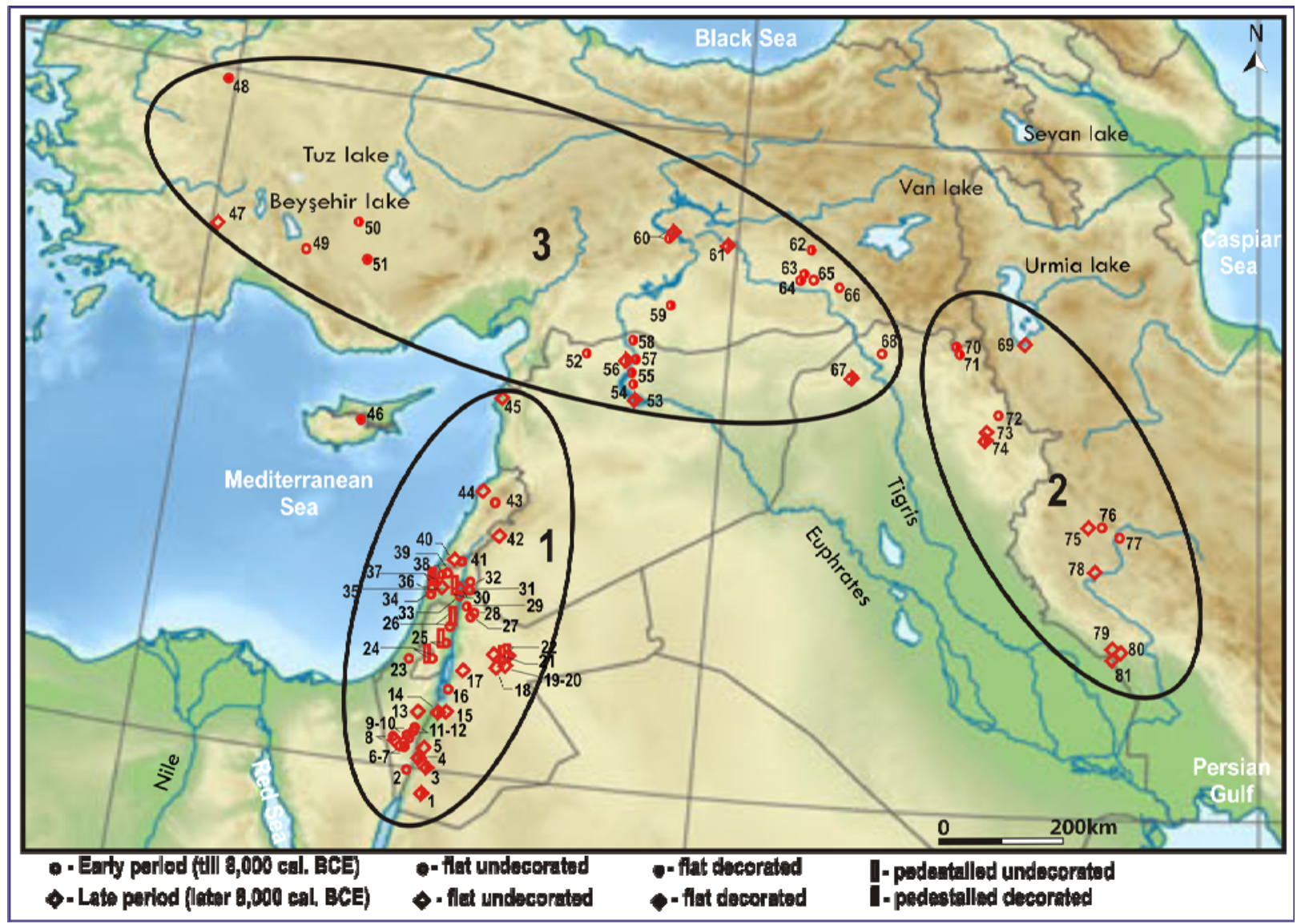

Figure 1. Distribution of grooved shaft straighteners in south-western Asia. (Relief_Map_of_Middle_East, Wikimedia Commons).1: the Levant; 2: the Zagros Mountains: 3: Central Anatolia \& Upper Mesopotamia. 1-Ain Abu Nekheileh, 2-Negev, site 83, 3-Basta, 4-Baaja, 5-Saqarat Masad 1, 6-Shluhat Harif, 7-Ramat Harif, 8-Abu Salem, 9-Shluhat Romam, 10-Romam, 11-Maaleh Ramon West, 12-Maaleh Ramon East, 13-Nahal Divshon, 14-Wadi Fainan 328, 15-Wadi Badda, 16-Zahrat adh-Drha، 2, 17-Es-Siffiya, 18-Azraq 31, 19-Jilat 32, 20-Jilat 25, 21-Jilat 13, 22-Jilat 7 , 23-Hatula, 24-El-Khiam, 25-Jericho, 26-Netiv Hagdud, 27-Beidha, 28-Shagaret M'siad, 29-Wadi Hammeh 27, 30-Munhata, 31-Sha'ar Hagolan, 32-Mudjahiya, 33-‘Erq el-Ahmar, 34-Mugharet el-Kebarah, 35-Raqefet Cave, 36-el-Wad (Wady el-Mughara), 37-Nahal Oren, 38-Hayonim Cave, layer B; Hayonim Terrace, 39-Me'arot Yonim , 40-Kfar HaHoresh, 41-Ain Mallaha (Mallaha, Eynan), 42-Ramad, 43-Saaïdé II, 44-Byblos, 45-Ras Shamra, 46-Ayia Varvara Asprokremnos, 47-Hacilar II, VI, 48-Demirci, 49-Suberde, 50-Boncuklu, 51-Pınarbaşı, 52-Qaramel, 53-Abu Hureyra, 54-Mureybet III, 55-Sheikh Nassan, 56-Halula, 57-Jerf el Ahmar, 58-Dja'de, 59-Göbekli , 60-Cafer , 61-Çayönü, 62-Hallan Çemi, 63-Demirköy, 64-Körtik Tepe, 65-Sumaki Höyük, 66-Gusir Höyük, 67-Kül , 68-Nemrik, 69-Hajji Firuz, 70-Zawi Chemi Shanidar , 71-Shanidar Cave, 72-Zarzi, 73-Jarmo, 74-Karim Shahir, 75-Sarab, 76-Tepe Asiab, 77-Ganj Dareh, 78-Guran, 79-Choga Sefid, 80-Sabz low., 81-Ali Kosh. 

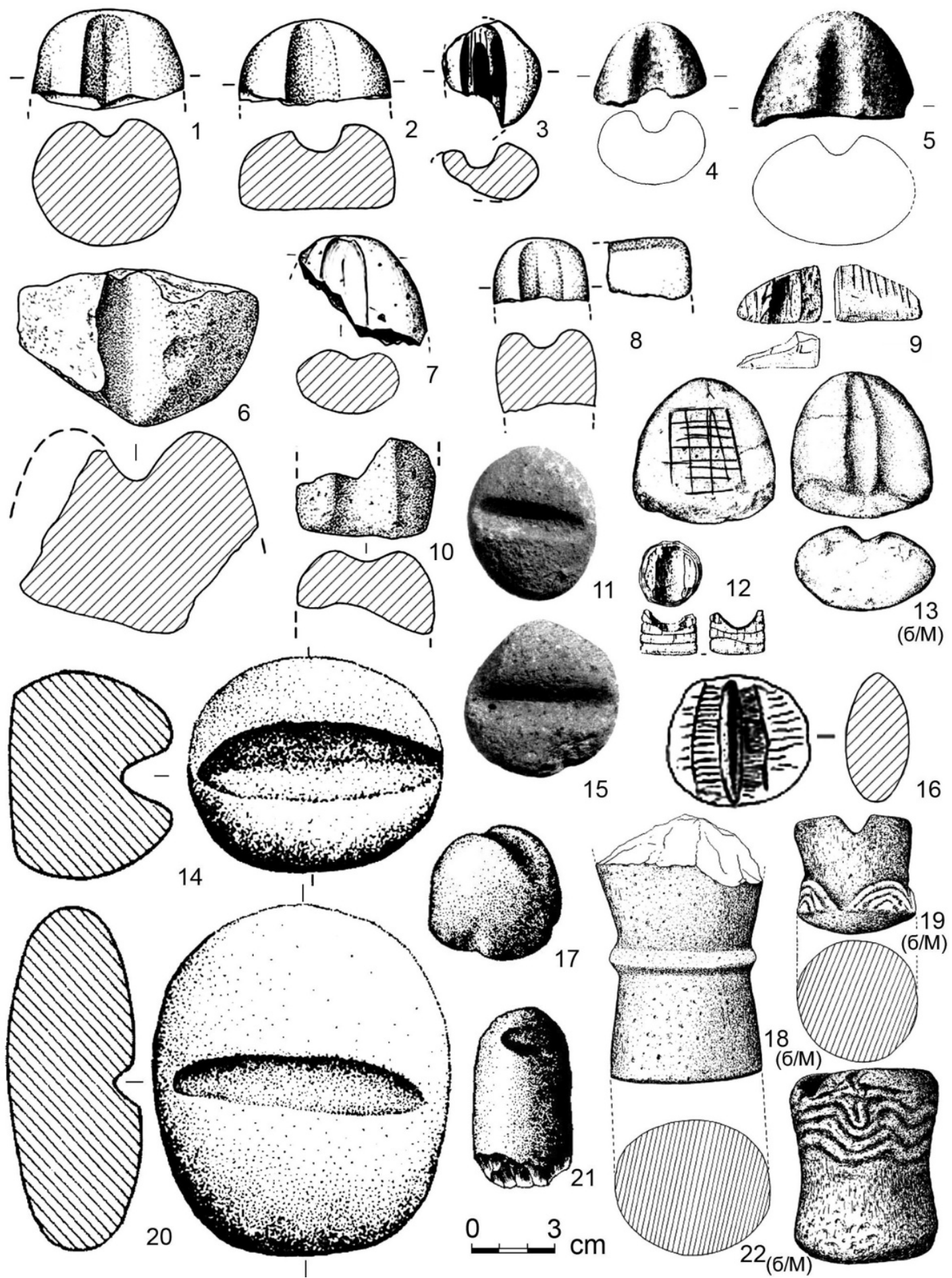

Figure 2. Natufian grooved stones (the Levant). 1-3, 6-8, 10: el-Wad Terrace (Rosenberg et al. 2012: 113, fig. 20, 1, 2, 4-6, 10; fig. 21, 2); 4-5: Beidha (Byrd 1991: 251, fig. 4, e, f); 9, 12: Hayonim Cave, Layer B (BelferCohen 1991: 576, fig. 6, 6-7); 11, 15: Saaïdé II (Schroeder 1991: 76, fig. 14, 1, 2); 13, 18, 19, 22: Nahal Oren (Noy 1991: 560, fig. 2, 5; 562, fig. 3, 1-3); 14, 20: Ali Kosh, Jericho (Kozlowski \& Aurenche 2005: 158, fig. 2.2.3.1, 1, 3); 16: Wadi Hammeh 27 (Edwards 1991: 134, fig. 8, 2); 17, 21: El-Khiam (Müller-Karpe 1968: fig. 102: C, 1-2). Without scale: 13, 18, 19, 22. 

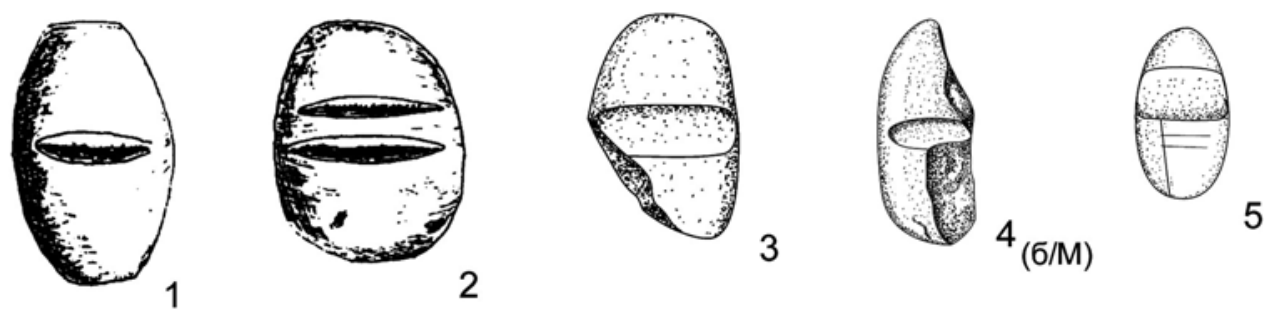

1

2

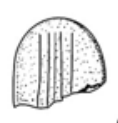

6

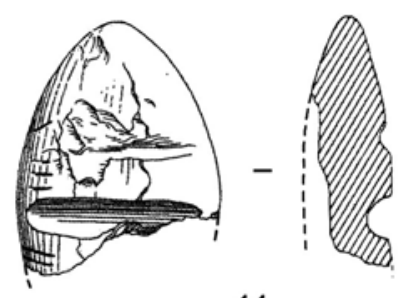

11
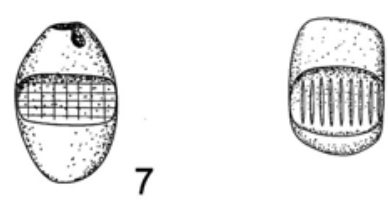

7

8
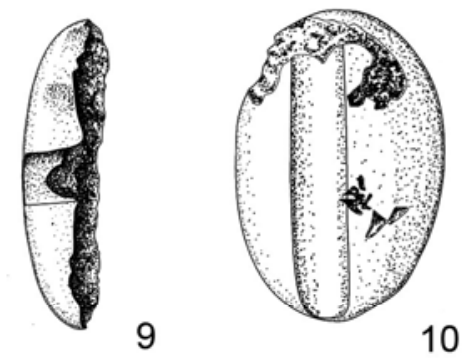

13
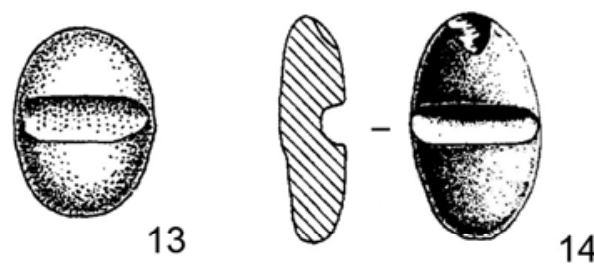

12

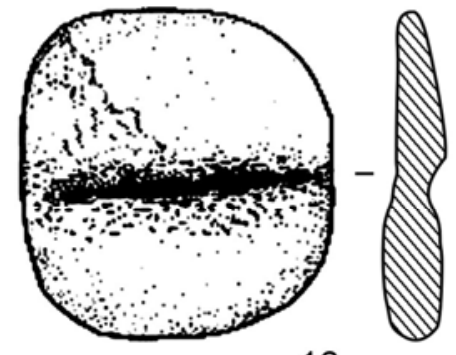

16
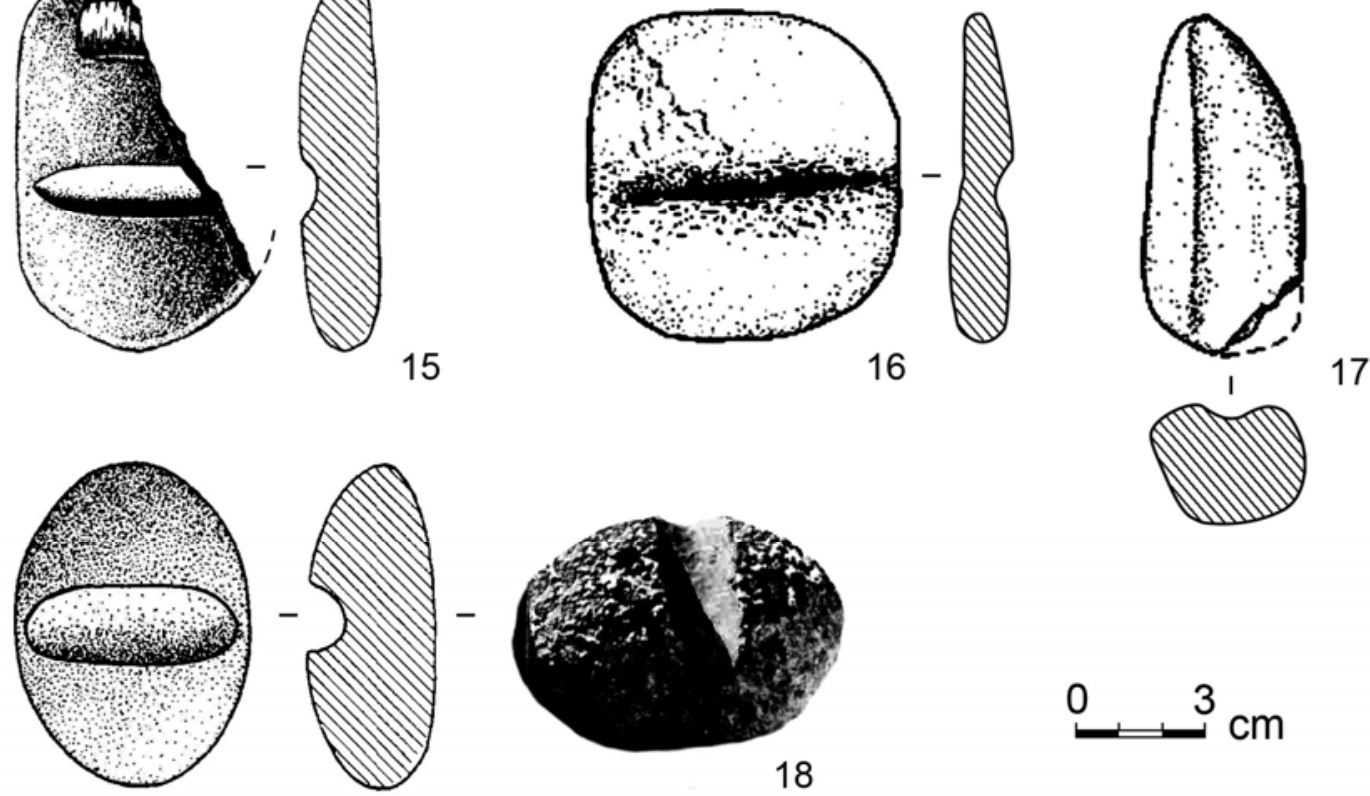

18

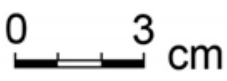

Figure 3. Epipalaeolithic through Pre-Pottery Neolithic grooved stones from the area of the Zagros Mountain and Negev Desert (Harifian Cultures). 1, 5-6: Shanidar Cave (Solecki \& Solecki 1970: 833, fig. 1, D, I, L); 2-4, 7-10: Zawi Chemi Shanidar (Solecki \& Solecki 1970: 833, fig. 1, A, B, C, E, F, G, H); 11-13: Karim Shahir (Howe 1983 fig. 12, 1, 2); 14-15, 18: Jarmo (Moholy-Nagy 1983: fig. 131, 12-14; fig. 140, 7); 16-17: Abu Salem, Harifian (Goring-Morris 1991: 197, fig. 16, 5, 6). 
TGS in Upper Mesopotamia are recorded, according to the preliminary information, within the framework of Early PPNA, slightly later than in the Levant and Zagros. The earliest datings, from Tell Qaramel, yield values ranging from the middle (12.464-11. $246 \mathrm{cal}$. $\mathrm{BP}, \pm 1 \sigma, \mathrm{H} 2)$ or the outset $12.898-11.670 \mathrm{cal}$. BP $, \pm 1 \sigma, \mathrm{H} 1)$ of the 11 th millennium cal. BCE (Mazurowski et al. 2009; Mazurowski \& Kanjou 2012: 28, 32). Although advanced forms of grooved products with complex decors suggest an earlier introduction in these areas.

It is interesting to note that Tell Qaramel is actually in the sphere of the Levant, more precisely, on its northern outskirts occupying a highly strategic position at the crossroads connecting the Levant, Mesopotamia, Anatolia, the Taurus Mountains and Egypt. Yet research at this site indicates that it is impossible to link it to either of the cultures of the Levant. According to Mazurovski \& Kanjou (2012: 28), the early horizon of the settlement (H1) belongs to an unidentified variant of the local Epipalaeolithic culture that shows differences with the Kebarian and Natufian traditions. Subsequent Horizon 2 bears the different attributes typical for the Levant Early PPNA combined with signs of incipient Qaramel tradition that would later manifest itself in the forms of arrow heads, architecture, and mainly, iconography. Representations would in fact become widespread in the rituals of northern Mesopotamia at the TGS sites and materials of the circular Göbekli Tepe (Mazurowski \& Kanjou 2012: 28). TGS shows evidence of a wide spread in northern Mesopotamia by the turn of the 10-11th millennia cal. BCE to the outset of the 11th millennium cal. BCE (Özdoğan et al. 2011: 270; Özkaya \& Coşkun 2011: 102-103).

Thus, according to the literature review, one can confidently state that the introduction of TGS in the Middle East is generally linked to the Epipalaeolithic and definitely associated with hunter-gatherers. The original source of this tradition remains nonetheless unclear, due to the different state of Epipalaeolithic territorial research and the modest number of radiocarbon dates of sites from the Zagros, Anatolia and Upper Mesopotamia. The view of the author is that the data tends to favour southern Levant or central Anatolia. The existence of a large network for the exchange of objects, ideas and knowledge in the Middle East during the Palaeolithic (Olszewski 2012: 9; Richter et al. 2011: 108) facilitated the rapid dissemination of innovation.

Also unclear is when the TGS ceased the existence in the Middle East. Certain data indicate the first half of the 6th millennium BCE. A sample from the Proto-Hassuna horizon at the early agricultural settlement of Kul Tepe (northern Mesopotamia) dates to this period (Bader 1982: 56, Fig. 4; 1989: 157, 201). Meanwhile, indirect data suggest that TGS in the Middle East survived at least until the 4th millennium BCE in sacred contexts. This is bolstered by TGS finds in the burial grounds of the Novosvobodnaya phase of the Maikop Culture stage in the Caucasus (Korobkova \& Sharovskaya 1983: 91; Popova 1963: table XVI, $3)$. The radiocarbon dating of Mound 31 at the tract Klady 3, (657-3,518 cal. BCE), which contains TGS, points to the middle of the 4th millennium cal. BCE (Korenevskiy 2008: 88, table 2). This phase, with no local roots, dates to the end of the second quarter of the 4th to the early 3rd millennium cal. BCE (Korenevskiy 2008: 88) and is distinguished by a very advanced level of metallurgy and metal processing that contrasts sharply with the archaic Neolithic stone and bone inventory (Munchaev 1982). Specific forms of its ceramic vessels made using the potter's wheel, the metal composition and certain other categories of artefacts (pins, seals, beads, and lapis lazuli) are analogous to examples in the Near East.

The greatest similarity of a number of artefacts and the order of radiocarbon dates are traced the Novosvobodnaya phase with the complexes of the Uruk period in northern Mesopotamia (Tepe Gavra XII-IX) and Amuk F phases in Syria (Korenevskiy 2008: 78-79, 82; Munchaev 1994: 34, 158). And although the issue about the existence of the Novosvobodnaya phase has yet to be fully resolved, there is consensus that it was conditioned by a powerful Middle Eastern impulse (Korenevskiy 2008: 81; Rezepkin 2004: 108). Yet it 
remains unclear why was this impulse leading to the emergence of new forms of tools, jewellery, weapons and pottery in the Caucasus associated with a return to an archaic stone industry, including TGS. This remains mysterious especially when considering the absence of TGA and microliths in both the 5th and the 4th millennium cal. BCE, both in Mesopotamia and in Syria. The only worthwhile explanation is the hypothesis advanced by Munchaev, and shared by the author of this paper, that certain products in Mesopotamia abandoned long before the 6-5th millennium cal. BCE could have served sporadically for cult ceremonies until the 3rd millennium cal. BCE (Munchaev 1994: 189). This is evidenced by the geometric microliths unearthed under the floors of Uruk temple. The similarity of these microliths with those of the assemblage of the richest Maikop mound is established. TGS would fit well into this model as a coeval of microliths in the Near East. Moreover, TGA are linked exclusively to extraordinary mound (Mound 31, Grave 5 of burial Klady is second only to the Maikop kurgan). Unconventional character of their use (along with traces of arrow straightening TGS bear traces associated with non-ferrous metallurgy) seems to confirm the sacral character of this set of products (Korobkova \& Sharovskaya 1983: 91).

Taking into account all the preceding arguments, TGS artefacts in the Near East as functional objects span the Epipalaeolithic to the end of Neolithic (Proto-Hassuna Culture, PN) and, presumably the Eneolithic to the Early Bronze (Uruk period) in sacred contexts as objects of cult. Most of the grooved artefacts belong to the first thousands years of their existence. Yet towards the end of the Pre-Pottery Neolithic (the 2nd half of PPNB) they decrease in number and persist mainly in remote desert sites such as Jilat or Abu Salem (Kozlowski \& Aurenche 2005: 24).

\section{Near Eastern TGS: typology, morphometrics, petrography and decor}

In the beginning of the 21 st century, Near Eastern GS were grouped into four types: 1) flat longitudinal, 2) flat transversal, 3) flat decorated and 4) "pedestaled", and some notions as to the peculiarities of their spread were traced (Kozlowski \& Aurenche 2005: 24). The simplest form ("flat undecorated") is ubiquitous and widely recorded (Figures 2: 1-8, 10-11, $14-15,20 \& 3,1-4,9-10,12-18)$. The western zone (the Levant) is therefore dominated by longitudinal grooved products (Type 1), whereas transverse grooved (Type 2) prevail in the eastern zone (the Zagros Mountain). A distinctive feature of Type 3 from northern Mesopotamia and part of the northern Levant is the decor resulting from engraving or emarginate (champlevé) carving regardless of groove orientation (Figures 4-6). This unique zone, christened by Kozlowski and Aurenche as "The Golden Triangle", is known for thousands of years to have served as a zone of contact between the two halves of the Fertile Crescent (Hole 1996; Kozlowski \& Aurenche, 2005: 46, 88-90; Olszewski 2012: 9). The supra-regional importance of this area is reflected not only in the originality of TGS but, first of all, in the early rise of the first long-term PPN settlements and cult complexes (see for example, Erim-Özdoğan 2011a,b; Kornienko 2006: 21, 174; 2016: 15, 17; Mazurowski \& Kanjou 2012; Özkaya \& Coşkun 2011; Schmidt 2006). Moreover, the largest part of TGS bearing decor is exclusively associated with these types of sites (Gebekli, Kortic Tepe, Tell Qaramel, etc.). It is noteworthy that TGS artefacts bearing relatively simple decor are recorded sporadically both in the Zagros and the Negev desert in the south of the Levant at the sites of, among others, Basta, Ain Abu Nekheileh, Wadi Fainan, where they form an independent group. Contrary to the main zone, all the GS finds of this last group date to the late period in the second half of the PPNB. It is also of note that the closest parallels to cult constructions of Upper Mesopotamia are identified just to the north of this area, at Jericho, Beida and Ain Ghasal (Kornienko 2006: 76). 

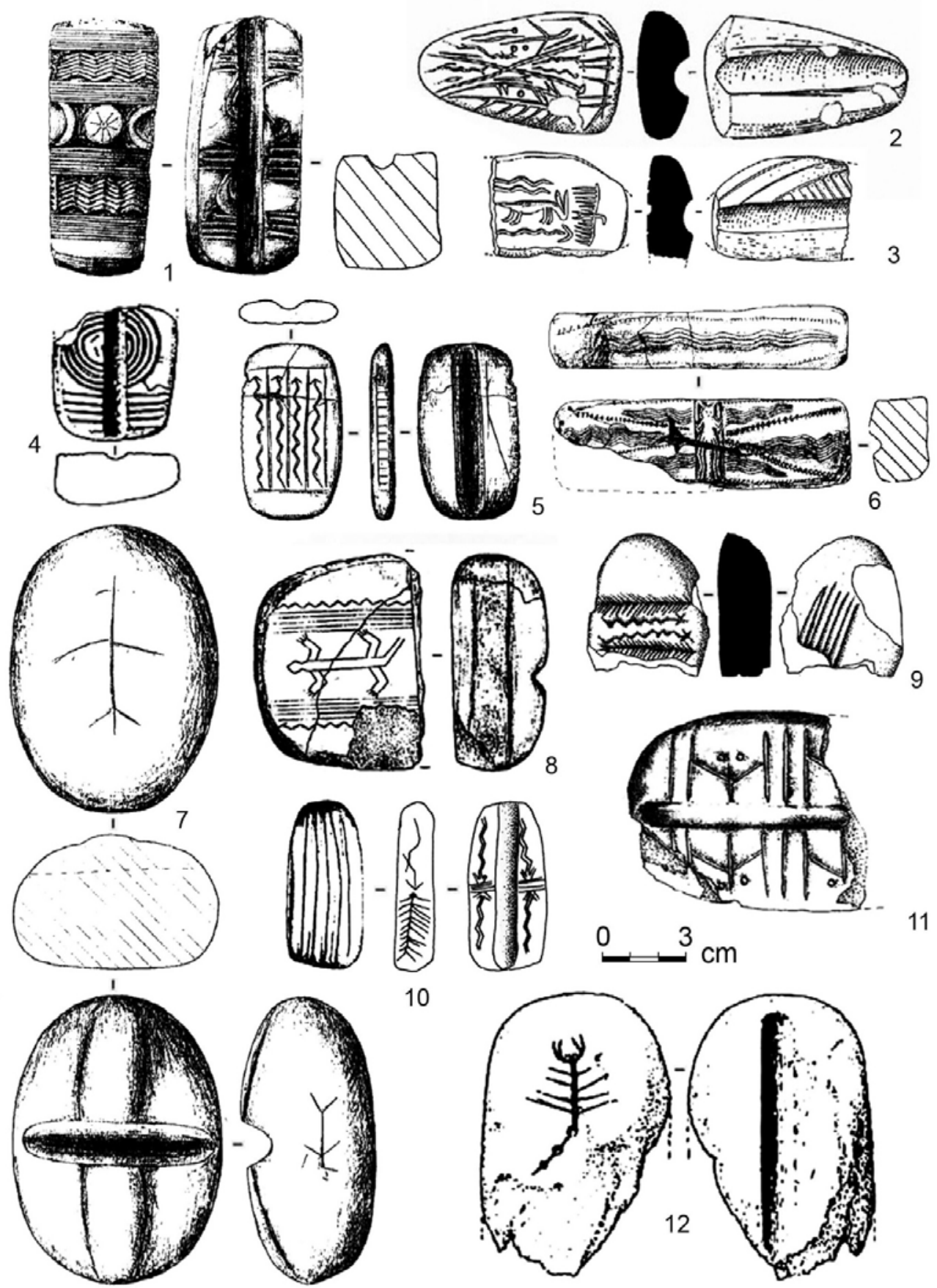

10

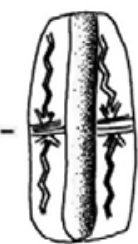

- $-3 \mathrm{~cm}$

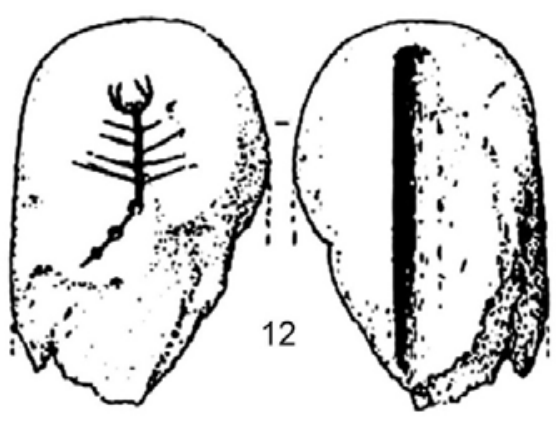

Figure 4. Grooved stones from "The Golden Triangle" (Upper Mesopotamia). 1, 5-11: Tell Qaramel (Mazurowski \& Kanjou 2012: fig. 68, 2, 4; 69, 3; 70, 3; 71, 372, 2; 75, 1; 79, 5); 2-4, 12: Jerf el Ahmar (Benz \& Bauer 2013: fig. 4, 6, 8, 10, 11). 


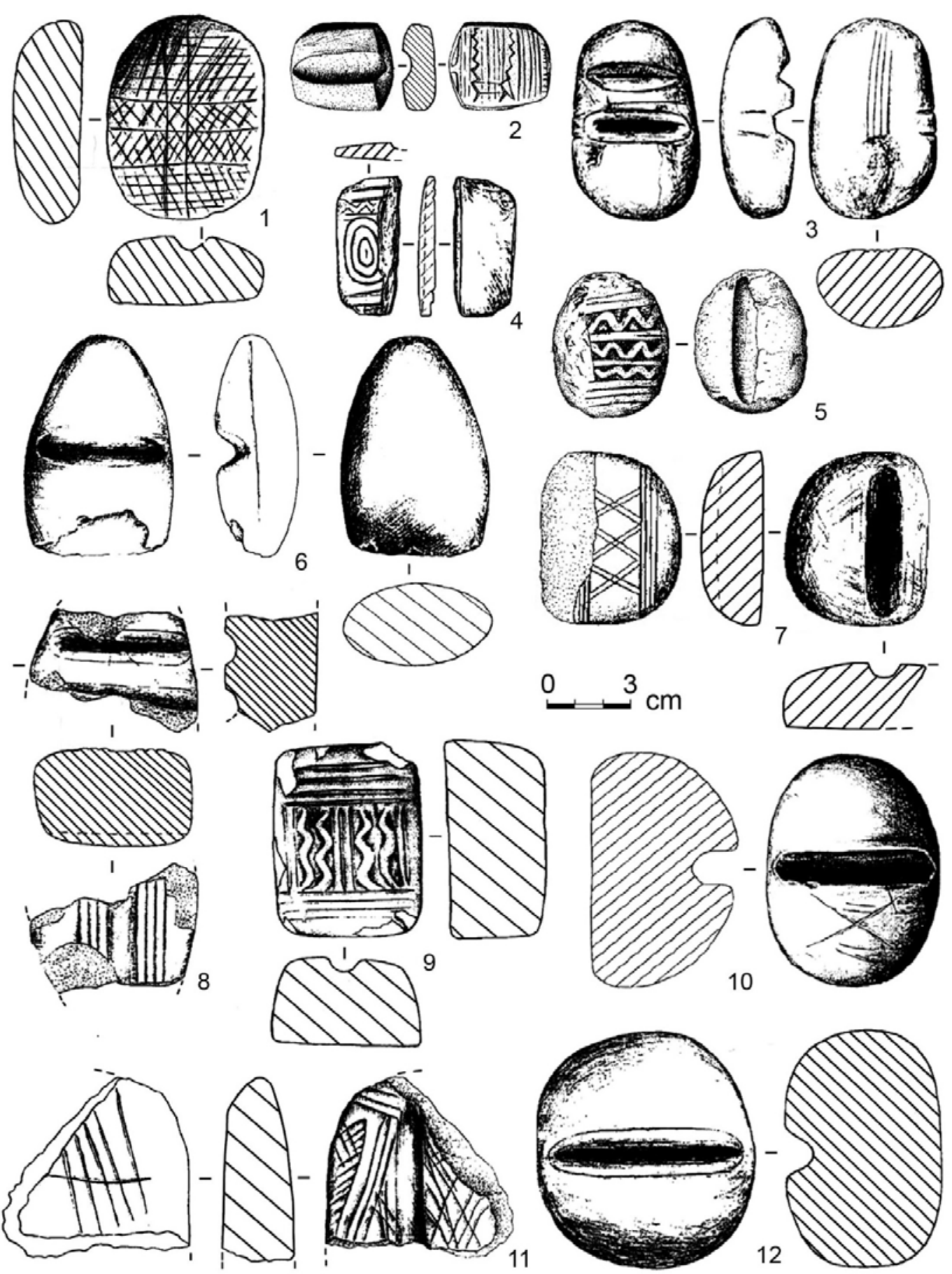

Figure 5. Grooved stones of "The Golden Triangle" (Upper Mesopotamia). 1, 3, 4, 6-12: Tell Qaramel (Mazurowski \& Kanjou 2012: fig. 68, 1; 69, 4; 71, 2; 73, 5; 74, 4; 75, 6; 77, 5; 78, 3, 4, 6); 2: Çayönü (Kozlowski \& Aurenche 2005: 2.2.3.3, 3); 5: Mureybet (Kozlowski \& Aurenche, 2005: 2.2.3.3, 1). 

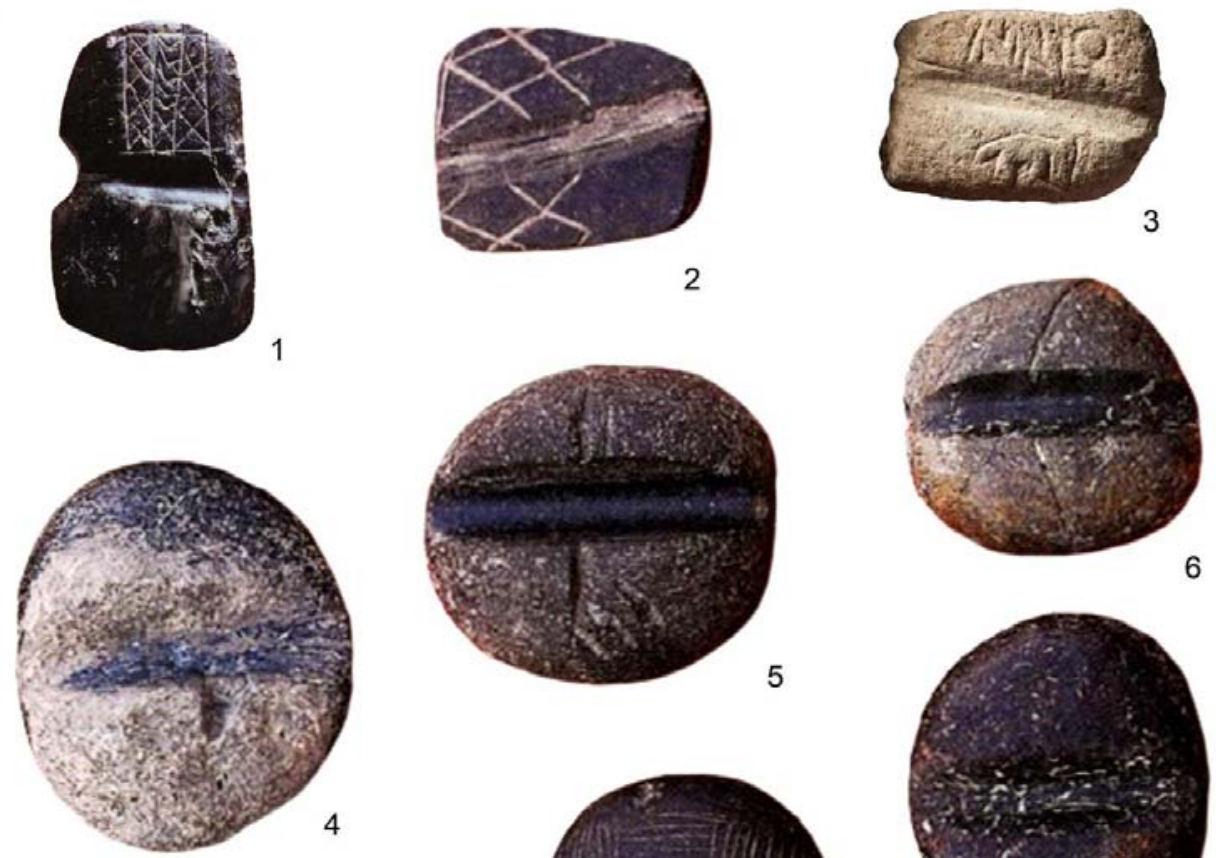

5
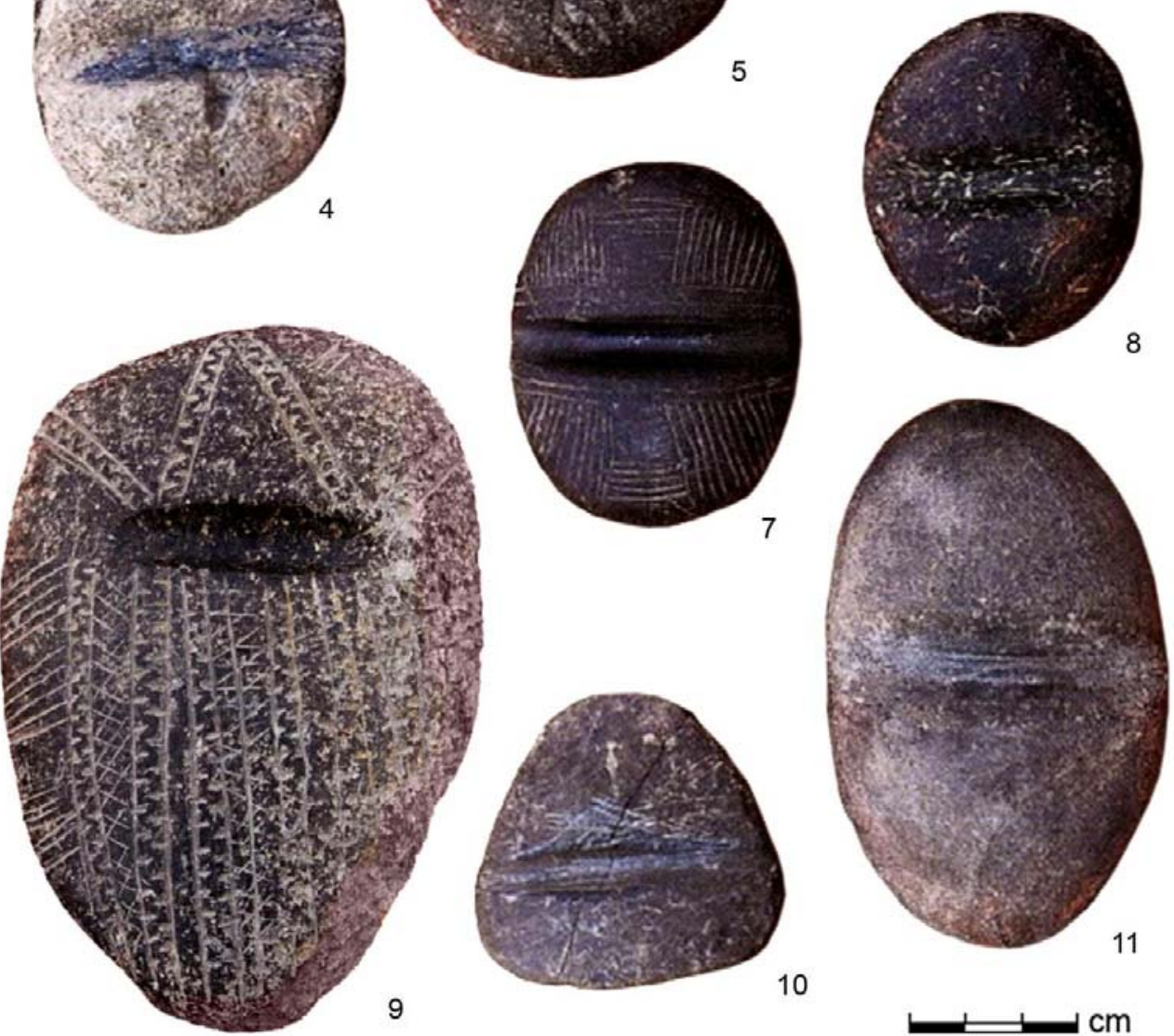

10

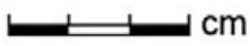

Figure 6. Grooved stones from "The Golden Triangle" (Upper Mesopotamia). 1: Cafer Höyük (Cauvin et al. 2011: 39, fig. 32); 2: Körtik Tepe (Özkaya \& Coşkun 2011: 124, fig. 26); 3: Göbekli Tepe (Dietrich et al. 2014: 16, fig. 13; Photo: N. Becker, DAI); 4-11: Körtik Tepe (Özkaya \& Coşkun 2011: 124, fig. 26, 27). 1, 3: without scale.

The fourth area is characterised by TGS of a special "pedestaled" form (Type 4). These artefacts are narrow, often oval in top view, with a height which is 1.5 to 2 times larger than the length. Finds of this type (Figure 2: 18, 19, 21,22) are recorded in a restricted area in the south of the Levant around Jericho and span the PPNB (Netiv Hagdud, Jilat 7, 12, Munhata, Azraq). They bear strong local specificities and are found only in this district. 
In spite of certain specifics, the morphometric characteristics of GS in the Near East do not differ from the relevant TGS indicators of northern Eurasia. Although they can be of different morphology, grooved stones of the early stages are usually made from simple oval pebbles (Byrd 1991: 259, Fig. 4; Edwards 1991; Goring-Morris 1991; Moholy-Nagy 1983; Rosenberg et al. 2012; Savage 2014: 123). Although often fragmented, their dimensions from a sampling of selected sites are similar. Those of the Natufian Culture measure 3.4-11.5 cm in length, 3.2-12 cm in width, and 3.2-17.6 cm in thickness (Savage 2014: 277-315). Those of the Shanidar-Karim-Shahir Culture, measure 3.1-8.7 cm in length, 2.0-4.7 cm in width, and 1.3-4.2 cm in thickness (Howe, 1983: 51-52; Solecki \& Solecki, 1970: 832), whereas those in the "Golden Triangle" measure 3.8-12.8 cm in length, 3.2-9.7 cm in width and $0.8-5.8 \mathrm{~cm}$ in thickness (Mazurowski \& Kanjou 2012: 215-229, Fig. 68-82). The diameter of the circumference inscribed in the groove is not recorded, but measurements of the width and the depth of the groove show a close range of values in different territories. The width of those of the Natufian Culture (19 examples) range from 1.1 to $2.1 \mathrm{~cm}$ with a depth between 0.3 to 1.3 cm (Savage 2014: 113, tab. 4.3-1; Schroeder 1991: 73;), Shanidar-Karim-Shahir Culture (about 20 examples), respectively 0.7 to $1.2 \mathrm{~cm}$ and 0.3 to $1.1 \mathrm{~cm}$ (Howe, 1983: 51-52; Solecki \& Solecki, 1970: 832); in the "Golden Triangle" (more than 40 examples): 1.0 to1.7 $\mathrm{cm}$ and 0.3to $1.6 \mathrm{~cm}$ (Mazurowski \& Kanjou 2012: 215-229, fig. 68-82). Differences in measurements are due to the lack of information.

The groove is either transverse or longitudinal. There are still no accurate statistical data, but according to preliminary observations, longitudinal grooves are more common in the Levant, particularly in the Natufian Culture (Figure 2), whereas their numbers are equal for the Zagros, Anatolia and northern Mesopotamian areas (Figures 3-6). At the end of the period the proportion of transverse grooves increases in all of the areas.

Comparative analysis also reveals differences of spread according to their morphology. Besides the widespread oval or oval to round type reflecting the form of the original pebbles, different areas have their own specific TGS-morphology resulting from a specifically intended shaping. These include, for example, the "pedestalled" TGS specific to an area of the Levant (Figure 2: 17-19, 21-22) or the boat-shaped TGS of Zagros (Figure 3: 11-12). The products of Upper Mesopotamia are characterised by a special variety of forms, high quality finishing and decors. These are found both in settlements and in ritual contexts of funerary or cultic constructions and complexes spanning the PPNA to the PN. Examples are known at Göbekli Tepe, Tell Qaramel, Körtik Tepe, and others (Mazurowski \& Kanjou 2012: 215-229; Özkaya \& Coşkun 2011: 97, Fig. 26-27). Certain forms comply with similar products from northern Eurasia (rectangular, teardrop-shaped, sub-triangular) while others (polygonal, semicircular) appear to be typical only of this region.

Cultural and chronological differences can be identified also by the type and technique of the décor as well as by the presence or absence of decor. For example, decors are not typical for Natufian basalt TGS, probably due to the rock's hardness (Mohs =6). Among classical ("flat") examples of the Natufian Culture, there are only simple linear engravings, such as at Wadi Hammeh 27 (Edwards 1991: Fig. 8, 2), Me'arot Yonim (Belfer-Cohen 1988: Fig. V-47), rectangular grid at Nahal Oren (Noy 1991: 558), or lateral incisions such as at the cave of Hayonim (Natufian Layer B, Belfer-Cohen 1991: 575, fig. 6, 6; Fig. 2, 9, 12-13, 16.). The decor of high ("pedestalled") TGS combining relief and carved elements is specific. There are three at the settlement of Nahal Oren (Noy 1991: 558, Fig. 3). The first is decorated by a ring in relief around its girth. The lower edge of the second has four rows of waves, while the upper area of the third has four rows of asymmetrical meanders (Figure 2: 9, 18-19, 22). Three deep rings are found along the body on the same "pedestalled" type at the Cave of Hayonim (Belfer-Cohen 1991: 575, Fig. 6, 7). It is noteworthy that all these motifs are 
characteristic of the Natufian Culture and also found on objects of bone and stone (Noy 1991: 561).

Decorative elements of TGS of the Zagros Mountains, in turn, are limited to elementary forms of longitudinal and transversal incisions (Figure 3: 5-8, 11). One example at the cave of Shanidar bears five longitudinal lines along the base while another have two lines parallel to the groove. Two cases at Zami Chemi Shanidar bear in grooves grid and a series of transverse incisions (Solecki \& Solecki 1970: 832-833, Fig. 1, L, D, E, and F). Triple incisions are recorded on both sides of the groove on a TGS fragment at the settlement of Karim Shahir (Howe 1983: 52, fig. 12, 1).

Decors of TGS in the "Golden Triangle" area are striking for its creative arts and crafts, and are widespread (up to 80\%) already in the Early PPNA (Mazurowski \& Kanjou 2012: 77). Local iconography of images both in small (shaft straighteners or stone plaques) and large forms (sculptures or, pillars) has bright originality. Decors on TGS of this region are characterised by a plot and style specifics (e.g., Erim-Özdoğan 2011a; Mazurowski \& Kanjou 2012; Özkaya \& Coşkun 2011; Rosenberg 2011). The decors show a wide range of complexity, from the simplest incisions to elaborate compositions of solar symbols, abstract geometrical ornaments, stylised anthropomorphic and zoomorphic figures such as snakes, scorpions, birds, beasts, and even an octopus (Figures 4-6). Different techniques of decorating are used: reliefs, carving (from simple linear to complex champlevé) and drilling. All are characterised by marked individuality in terms of size, form, and decor.

\section{Discussion}

Comparing the Near Eastern GS with the TGS of northern Eurasia reveals a wide spread of Type 2 (transverse grooved) and Type 3 (decorated), in contrast to isolated cases of Type 1 (longitudinal grooved) and Type 4 ("pedestaled") that is totally absent. The three major areas corresponding to the spread of GS meet the geographical and cultural specificities of these areas. They might actually be the result of these circumstances although other factors cannot be excluded. This bolsters the notion advanced by Kozlowski and Aurenche that longitudinal grooves are more common in the Levant (Kozlowski \& Aurenche 2005: 24). Yet transverse grooves appear to dominate in the Zagros, Anatolia and northern Mesopotamia. However, the current data suggests that the differences in the geographical spread is not linked to the cultural specificities only, but depends on the different rock types in specific cases. Transverse grooves are typical of artefacts made of steatite, talc, chlorite and other similar soft non-abrasive schists. Longitudinal grooves, by contrast, prevail in the areas devoid of steatite. There are no rocks of talc-chlorite, for example, in the Levant (see for example, Wright 1992: 53-55). This type of rock was selected for TGS in Northern Eurasia, Northern and Southern America and some other regions. Alternatively, dense basalt pebbles and sporadically limestone and aragonite are mostly often used in the Levant (e.g., Edwards 1991: 129, 133, 136; Noy 1991: 558; Rosenberg et al. 2014: 112; Savage 2014: 113-114, Tab. 4.31; Solecki \& Solecki 1970: 835). Since these rocks are more brittle than talc-chlorite, it is possible that the increase of the groove length (in the case of longitudinal type) could presumably afford them with a longer use life. This is probably the same reason that there are many high and very high forms. Finally, the presence of individual objects from sandstone, diorite, and scoria in the earliest collections of GS in the company of the products from nonabrasive rocks allows to see in these artefacts the origin of not only TGS, but also longitudinal grooved abraders or calibrators (straighteners for wood shafts), an artefact that was widespread in the forest Neolithic cultures of Europe and Asia (e.g. Müller-Karpe 1968: pl. 134, 201, 400; Oshibkina 1996: Fig. 88, 96; Semenov 1968: 109-110). Contrary to the Levant, the stone artefact from the sites of Zagros and the Upper Mesopotamia were made mainly 
from steatite, chlorite and similar soft and medium soft rocks (Drew 1970; Erim-Özdoğan 2011: 218; Howe 1983: 51, 127; Mazurowski \& Kanjou 2012: 76; Solecki \& Solecki 1970: 831; Rosenberg 2011: 81). These very resistant rocks resulted in an immediate increase of the number of artefacts bearing transverse grooves.

The general morphology of GS also requires clarification. First of all, there are two type shapes: natural and artificial. It is now clear that the early chronological phase, and certain later cases, were dominated by oval to round forms reflecting a choice of natural pebbles shaped by water transport (Savage 2014: 123, 318; Usacheva 2016: 595). These required no or a minimum degree of fashioning procedures. With time, artificial forms progressively became more widespread. This led to the development of specific forms of GS in each zone that, in turn, help to identify cultural differences. These differences are highlighted by the "pedestaled" GS of the Levant or the boat-shaped artefacts of Zagros (Figure 3: 11-12). This is especially the case of artefacts of Upper Mesopotamia characterised by a wide variety of forms, including examples that are geometric. Certain forms comply with similar artefacts in northern Eurasia that are rectangular, teardrop-shaped or sub-triangular, while other polygonal or semi-circular forms appear to be typical only of Upper Mesopotamia. TGS using artificial forms are most often decorated. The origins of this tradition remain unclear. There is no evidence of continuity in the Levant and Zagros Cultures (Berezkin 2014: 206; Schmidt 2006: 65). The Anatolian Plateau perhaps merits more attention due to the uniqueness and specificity of its TGS. This could, to some extent, be associated with a series of ancient cult complexes and their settlements that would have been connected by a common "symbolic language" (Baird 2012: 441; 2017: 770; Schmidt 2011: 52). It is therefore most likely this area saw the initial sacralisation of TGS observed later in northern regions (Usacheva 2013b: 128).

It should be noted that distinct decorative elements, entire compositions and many forms of Near Eastern GS find direct parallels with the northern Eurasia materials (e.g., Usacheva 2013b: 111-119; 2016). Their comparative analysis requires special analyses and targeted research on the remaining unclear indicators of the specific characteristics of zones types. These include an extension of the number of morphological and decorative indicators for the fashioned artificial artefacts such as the general form, the longitudinal section, the cross section and the varieties of decor. These factors are important, in particular, to reveal the initial points of the spread of the cultural traditions that can be clearly read from the decor and morphology of TGS finds beyond the Near East. In Northern Eurasia, for example, there are over two dozen types of forms and almost as many decorative combinations (Usacheva 2013b: 40-55).

\section{Conclusion}

The earliest transverse grooved stones of Eurasia are made of non-abrasive raw materials and appear not later than in the middle of 13th millennium cal. BCE in south-western Asia among hunter-gatherers. In general, they span the Epipalaeolithic (Mesolithic) to the end of the Neolithic. In certain exceptional cases (ritual contexts) they are present in the subsequent Eneolithic - Early Bronze Age (Uruk period). The geographical spread of grooved artefacts of this type is limited to the area of central Anatolia and the Fertile Crescent, with a boundary along the desert-steppes. Three concentrations can be clearly distinguished: the Levant, the Zagros Mountains, and Upper Mesopotamia - central Anatolia. The earliest cases are recorded in the Early Natufian contexts in the Levant and in the Epipalaeolithic contexts of the Anatolian plateau, since the 13th millennium cal. BCE. The original forms of these tools in the Levant were oval to round, following the forms of the natural oval pebbles used to make them. A distinct preference was afforded to pebbles of non-abrasive rocks, such as dense 
basalt. The grooves of these first GS do not show a stable transverse orientation in spite of the fact that they already bear the characteristic features of the morphology of this tool, i.e., a smoothly curved groove profile, parallel side walls, a flat bottom line and a 0.7 to $2.1 \mathrm{~cm}$ range in diameter. Natufian GS from morphological and chronological standpoints are analogous to those of Zagros that are dated since 12th millennium cal. BCE. That time saw the use of steatite, chlorite, talc and other soft non-abrasive rocks to produce TGS. It is these rocks that were subsequently most widespread in Northern Eurasia and large parts of the Near East. Thus, in the course of an adaptation to the locally available raw materials, the most appropriate material for the production of reed and cane shafts straighteners was discovered and used, and led to it a subsequent standardization. Not later than in about the middle of the 11th millennium BCE, settlements and ritual complexes of the "Golden Triangle" (Upper Mesopotamia) saw a great use of TGS in different forms, finished qualities and decor. Afterwards, their number decreases gradually, parallel with the proceeding development of producing forms of economy.

The comparison of the forms and decors of grooved stones from south-western Asia to those of Northern Eurasia is an effective means to determine the pathways of distribution of specific cultural traditions and directions of transcultural contacts in these areas from the Epipalaeolithic to the Early Bronze Age.

\section{Acknowledgements}

I would like to express my gratitude to my Russian colleagues, too numerous to mention individually, who have generously shared information and allowed examination of the grooved stone tools from their excavations. Special thanks also go to D. Rosenberg (Zinman Institute of Archaeology, University of Haifa), T. Korniyenko (Voronezh State Pedagogical University), J. Robitaiile (Ecole des Haute Etudes en Sciences Sociales, Paris and A. Stroulia (Indiana University, Bloomington) who contributed photographs, articles and personal information stimulating this research. I also thank the AGSTR organising committee for the informative conferences and my son, Evgeny, for financial support to attend the meetings. This research was carried out under the project of the Ministry of Science and Higher Education No. 121041600045-8 "Western Siberia in the context of Eurasian relations: man, nature, society".

\section{References}

Bader, N.O. 1982, Nekotorye rezul'taty rabot na rannezemledel'cheskom poselenii Kyul'tepe v Severnom Irake. In: Arheologiya Starogo i Novogo Sveta (Gulyaev, V.I., Ed.), Nauka, Moscow: p. 50-57. (in Russian) ("Results of the Excavations at the Early Agricultural Site of Kül Tepe in Northern Iraq")

Bader, N.O. 1989, Drevnejshie zemledel'cy Severnoj Mesopotamii: issledovaniya Sovetskoj arheologicheskoj ekspedicii v Irake na poseleniyah tell' Magzaliya, tell' Sotto, Kyul'tepe. Nauka, Moscow, 365 p. (in Russian) ("Earliest cultivators in Northern Mesopotamia: the investigations of Soviet archaeological expedition in Iraq at Settlements Tell Magzaliya, Tell Sotto, Küll Tepe”)

Baird, D. 2012, The Late Epipaleolithic, Neolithic, and Chalcolithic of the Anatolian Plateau, 13,000-4000 BC. In: A Companion to the Archaeology of the Ancient Near East (Vol. 1). (Potts, D.T., Ed.), Blackwell Publishing Ltd., Malden: p. 431-465. doi:10.1002/9781444360790.ch23 
Baird, D., Asouti, E., Astruc, L., Baysal, A., Baysal, E., Carruthers, D., Fairbairn, A., Kabukcu, C., Jenkins, E., Lorentz, K., Middleton, C., Pearson, J., \& Pirie, A. 2013, Juniper smoke, skulls and wolves' tails. The Epipalaeolithic of the Anatolian plateau in its South-west Asian context; insights from Pinarbaşi. Levant, 45(2): 175-209. doi:10.1179/0075891413z.00000000024

Baird, D., Fairbairn, A. \& Martin, L. 2017, The animate house, the institutionalization of the household in Neolithic central Anatolia. World Archaeology, 49(5): 753-776. doi:10.1080/00438243.2016.1215259

Bar-Yosef, O. 1998, The Natufian culture in the Levant, threshold to the origins of agriculture. Evolutionary Anthropology, 6(5): 159-177. doi:10.1002/(sici)15206505(1998)6:5\%3C159::aid-evan4\%3E3.0.co;2-7

Belfer-Cohen, A. 1988, The Natufian settlement at Hayonim Cave: a hunter-gatherer band on the threshold of agriculture. Unpublished Ph.D. Dissertation, The Hebrew University, Jerusalem, $603 \mathrm{p}$.

Belfer-Cohen, A. 1991, Art items from Layer B, Hayonim Cave: a case study of art in a Natufian context. In: The Natufian culture in the Levant (Bar-Yosef, O. \& Valla, F.R., Eds.), International Monographs in Prehistory, Ann Arbor, Michigan: p. 569-588.

Benz, M. \& Bauer, J. 2013, Symbols of power-symbols of crisis? A psycho-social approach to Early Neolithic symbol systems. Neo-lithics, 2: 11-24.

Berezkin, Yu. E. 2014, Varianty politogeneza v dogosudarstvennuyu epohu i podhody $\mathrm{k}$ ih izucheniyu. Antropologicheskij forum, 20: 187-217. (in Russian) ("Different models of political development in the pre-state epoch and their study approaches")

Byrd, B.F. 1991, Beidha: an Early Natufian encampment in southern Jordan. In: The Natufian culture in the Levant (Bar-Yosef, O. \& Valla, F.R., Eds.), International Monographs in Prehistory, Ann Arbor, Michigan: p. 245-264.

Cauvin, J., Aurenche, O., Cauvin, M.C. \& Balkan-Atli, N. 2011, The Pre-Pottery site of Cafer Höyük. In: The Neolithic in Turkey: New Excavations \& New Research, Vol. 2: The Euphrates Basin (Özdogan, M., Baçgelën, N., \& Kuniholm, P., Eds.), Archaeology \& Art Publications, Istanbul: p. 1-40.

Çilingiroğlu, Ç. 2005, The concept of "Neolithic package": considering its meaning and applicability. Documenta Praehistorica, 32: 1-13. doi:10.4312/dp.32.1

Dietrich, O., Köksal-Schmidt, Ç., Kürkçüoğlu, C., Notroff, J. \& Schmidt K. 2014, Göbekli Tepe. Preliminary Report on the 2012 and 2013 Excavation Seasons. Neo-Lithics, 1: 1117.

Drew, I.M. 1970, Laboratory Report. American Anthropologist, 72(4): 839-840. doi:10.1525/aa.1970.72.4.02a00080

Edwards, P.C. 1991, Wadi Hammeh 27: An Early Natufian site at Pella, Jordan. In: The Natufian culture in the Levant (Bar-Yosef, O. \& Valla, F.R., Eds.), International Monographs in Prehistory, Ann Arbor, Michigan: p. 123-148.

Erim-Özdoğan, A. 2011a, Çayönü. In: The Neolithic in Turkey: New Excavations \& New Research: The Tigris Basin (Özdogan, M., Baçgelën, N., \& Kuniholm, P., Eds.), Archaeology \& Art Publications, Istanbul: p. 185-269. 
Erim-Özdoğan, A. 2011b, Sumaki Höyük. A New Neolithic Settlement in the Upper Tigris Basin. The Neolithic in Turkey. New excavations \& New Research. The Tigris Basin (Özdogan, M., Baçgelën, N., \& Kuniholm, P., Eds.), Archaeology \& Art Publications, Istanbul: p. 19-60.

Garrod, D. A. E. 1930, The Paleolithic of southern Kurdistan: excavations in the caves of Zarzi and Hazar Merd. Bulletin of the American School of Prehistoric Research, 6: 843.

Goring-Morris, A.N. 1991, The Harifian of the southern Levant. In: The Natufian culture in the Levant (Bar-Yosef, O. \& Valla, F.R., Eds.), International Monographs in Prehistory, Ann Arbor, Michigan: p. 173-216.

Hole, F. 1996, A Syrian Bridge between the Levant and the Zagros. In: Neolithic Chipped Stone Industries of the Fertile Crescent, and Their Contemporaries in Adjacent Regions; Proceedings of the Second Workshop on PPN Chipped Lithic Industries, 1995, Warsaw (Kozlowski, S.K., \& Gebel, H.G.K., Eds.), ex Oriente e. V., Berlin: p. 5-14.

Howe, B. 1983, Karim Shahir. In: Prehistoric Archaeology along the Zagros Flanks (Braidwood, L.S., Braidwood, R.J., Howe, B., Reed, C.A., \& Watson, P.J. Eds.), Oriental Institute Publications Vol. 105. The University of Chicago Press, Chicago: p. 23-157.

Korenevskiy, S.N. 2008, Sovremennye problemy izucheniya Majkopskoj kul'tury. In: Arheologiya Kavkaza i Blizhnego Vostoka. TAUS, Moskow: p. 71-122. (in Russian) ("Modern problems of investigation of the Maikop culture")

Kornienko, T.V. 2006, Pervye hramy Mesopotamii. Formirovanie tradicii kul'tovogo stroitel'stva na territorii Mesopotamii v dopis'mennuyu epohu. Aletejya, Saint Petersburg, 312 p. (in Russian) ("The First Temples of Mesopotamia: Forming the Tradition of Cult Construction in Prehistoric Mesopotamia")

Kornienko, T.V. 2016, Profannyj i sakral'n'ij kontekst zhilishch Severnoj Mesopotamii na etape stanovleniya neolita. Vestnik Voronezhskogo Gosudarstvennogo Universiteta, 1: 10-21. (in Russian) ("Profane and sacred context of dwellings Northern Mesopotamia at the stage of formation of the Neolithic"). URL:http://www.vestnik.vsu.ru/pdf/history/2016/01/2016-01-02.pdf

Korobkova, G.F. \& Sharovskaya, T.A. 1983, Funkcional'nyj analiz kamennyh i kostyanyh izdelij iz kurganov epohi rannej bronzy u stanic Novosvobodnoj i Baturinskoj. In: Drevnie kul'tury evrazijskih stepej (Masson, V.M., Ed.), Nauka, Leningrad: p. 88-94. (in Russian) ("Functional analysis of stone and bone implements from barrows of Early Bronze Age near villages Novosvobodnaya and Baturinskaya")

Kozlowski, S.K. \& Aurenche, O. 2005, Territories, boundaries and cultures in the Neolithic Near East. BAR International Series Vol. 1362, Archaeopress, Oxford, 275 p.

Mazurowski, R.F. \& Kanjou, Y., (Eds.), 2012, Tell Qaramel 1999-2007: Protoneolithic and Early Pre-pottery Neolithic Settlement in Northern Syria. Preliminary results of SyrianPolish archaeological excavations 1999-2007. Polish Centre of Mediterranean Archaeology, Excavation Series 2, University of Warsaw, Warsaw, 289 p.

Mazurowski, R.F., Michczyńska, D.J., Pazdur, A. \& Piotrowska, N. 2009, Chronology of the early Pre-Pottery Neolithic settlement Tell Qaramel, northern Syria, in the light of radiocarbon dating. Radiocarbon, 51(2): 771-781. doi:10.1017/S0033822200056083 
Moholy-Nagy, H. 1983, Jarmo artifacts of pecked and ground stone and of shell. In: Prehistoric Archaeology along the Zagros Flanks, (Braidwood, L.S., Braidwood, R.J., Howe, B., Reed, C.A., \& Watson, P.J., Eds.), Oriental Institute Publications 105. The University of Chicago Press, Chicago: p. 290-346.

Müller-Karpe, H. 1968, Handbuch der Vorgeschichte. Jungsteinzeit, Vol. 2. Beck, Munich, 612 p. (in German) ("Handbook of History. Neolithic")

Munchaev, R.M. 1982, Eneolit Kavkaza. In: Eneolit SSSR. Arheologiya SSSR, (Masson, V.M., \& Merpert, N.Ya., Eds.), Nauka, Mokow: p. 93-164. (in Russian) (“The Eneolithic of the Caucasus").

URL:http://www.archaeolog.ru/media/books_arch_ussr/ArchaeologyUSSR_03.pdf

Munchaev, R.M. 1994, Majkopskaya kul'tura. In: Epoha bronzy Kavkaza i Srednej Azii. Rannyaya i srednyaya bronza Kavkaza. Arheologiya, (Kushnareva, K.H., \& Morkovin, V.I., Eds.), Nauka, Moscow: p. 158-225. (in Russian) ("The Maikop culture"). URL: http://www.archaeolog.ru/media/books_arch_ussr/ArchaeologyUSSR_14.pdf

Noy, T. 1991, Art and decoration of the Natufian at Nahal Oren. In: The Natufian culture in the Levant (Bar-Yosef, O., \& Valla, F.R., Eds.), International Monographs in Prehistory, Ann Arbor, Michigan: p. 557-568.

Olszewski, D.I. 2012, The Zarzian in the Context of the Epipaleolithic Middle East. The International Journal of Humanities, 19(3): 1-20.

Oparin, V.N. \& Tanaino A.S. 2015, A new method to test rock abrasiveness based on physico-mechanical and structural properties of rocks. Journal of Rock Mechanics and Geotechnical Engineering, 7: 250-255. doi:10.1016/j.jrmge.2014.12.004

Oshibkina, S.V. (Ed.) 1996, Neolit Severnoj Evrazii. Arheologiya, Nauka, Moskow, 380 p. (in Russian) ("The Neolithic of Northern Eurasia"). URL: http://www.archaeolog.ru/media/books_arch_ussr/ArchaeologyUSSR_15.pdf

Özdogan, M., Baçgelën, N., \& Kuniholm, P., (Eds.) 2011, The Neolithic in Turkey: New Excavations \& New Research: The Tigris Basin, Archaeology \& Art Publications, Istanbul, $271 \mathrm{p}$.

Özkaya, V., Coşkun, A. 2011, Körtik Tepe. In: The Neolithic in Turkey: New Excavations \& New Research: The Tigris Basin, (Özdogan, M., Baçgelën, N., \& Kuniholm, P., Eds.), Archaeology \& Art Publications, Istanbul: p. 89-127.

Popova, T.B. 1963, Dol'meny stanicy Novosvobodnoj. In: Trudy Gosudarstvennogo Istoricheskogo muzeya. Vol. 34. Sov. Rossiya, Moscow, 96 p. (in Russian) ("Dolmens of the Stanitsa Novosvobodnaya")

Ramsey, B.C. 2005, OxCal V 3.10. URL: http://c14.arch.ox.ac.uk/oxcal3/oxcal.htm

Reimer, P.J., Baillie, M.G.L., Bard, E., Bayliss, A., Beck, J.W., Bertrand, C., Blackwell, P.G., Buck, C.E., Burr, G., Cutler, K.B., Damon, P.E., Edwards, R.L., Fairbanks, R.G., Friedrich, M., Guilderson, T.P., Hughen, K.A., Kromer, B., McCormac, F.G., Manning, S., Bronk Ramsey, C., Reimer, R.W., Remmele, S., Southon, J.R., Stuiver, M., Talamo, S., Taylor, F.W., van der Plicht J. \& Weyhenmeyer C.E. 2004, IntCal04 terrestrial radiocarbon age calibration, 0-26 Cal kyr BP. Radiocarbon, 46: 1029-1058. doi:10.1017/S0033822200032999

Rezepkin, A.D. 2004, Nekotorye aspekty formirovaniya epohi rannej bronzy na Severnom Kavkaze. In: Materialy i issledovaniya po arheologii Kubani Vol. 4, (Marchenko, I.I., 
Ed.), Krasnodar: 97-125. (in Russian) ("Some aspects of the early bronze formation in the North Caucasus")

Richter, T., Garrard, A.N., Allock, S. \& Maher, L.A. 2011, Interaction before agriculture: exchanging material and sharing knowledge in the Final Pleistocene Levant. Cambridge Archaeological Journal, 21(1): 95-114. doi:10.1017/S0959774311000060

Rosenberg, D., Kaufman, D., Yeshurun, R. \& Weinstein-Evron, M. 2012, The broken record: The Natufian groundstone assemblage from el-Wad Terrace (Mount Carmel, Israel) Attributes and their interpretation. Eurasian Prehistory, 9(1-2): 93-128.

Rosenberg, M. 2011, Demirköy. In: The Neolithic in Turkey: New Excavations \& New Research: The Tigris Basin (Özdogan, M., Başgelën, N., \& Kuniholm, P., Eds.), Archaeology \& Art Publications, Istanbul: p. 79-87.

Savage, D. 2014, Arrows Before Agriculture? A Functional Study of Natufian and Neolithic Grooved Stones. Unpublished MA Thesis no. AAC1564003, Trent University, Peterborough, Canada, 327 p.

Schmidt, K. 2006, Sie bauten die ersten Tempel: Das rätselhafte Heiligtum der Steinzeitjäger: Die archäologische Entdeckung am Göbekli Tepe. Verlag C.H. Beck, Munich, 282 p. (in German) ("They Built the First Temples: The Mysterious Sanctuary of the Stone Age Hunters: Archaeological Discoveries at Gobekli Tepe")

Schmidt, K. 2011, Göbekli Tepe. In: The Neolithic in Turkey: New Excavations \& New Research Vol. 2: The Euphrates Basin, (Özdogan, M., Baçgelën, N., \& Kuniholm, P., Eds.), Archaeology \& Art Publications, Istanbul: p. 41-83.

Schroeder, B. 1991, Natufian in the Central Béqaa Valley. In: The Natufian culture in the Levant (Bar-Yosef, O., \& Valla, F.R., Eds.), International Monographs in Prehistory, Ann Arbor, Michigan: p. 43-80.

Semenov, S.A. 1968, Razvitie tekhniki v kamennom veke. Nаука, Leningrad, 363 p. (in Russian) ("The development of technology in Stone Age")

Solecki, R.L. \& Solecki, R.S. 1970, Grooved stones from Zawi Chemi Shanidar, a Protoneolithic site in northern Iraq. American Anthropologist, 72(4): 831-841. doi:10.1525/aa.1970.72.4.02a00080

Stroulia, A. 2010, Flexible Stones: Ground Stone Tools from Franchthi Cave, Excavations at Franchthi Cave, Greece, Fascicle 14 (Jacobsen, T.W., \& Vitelli, K.D., Eds.). Indiana University Press, Bloomington and Indianapolis, 223 p.

Usacheva, I.V. 2006, "Utyuzhki” v kul'turah Evrazii. Vestnik arkheologii, antropologii $i$ etnografii, 6: 12-23. (in Russian) (“"Utyuzhki” in the cultures of Eurasia”). URL: http://www.ipdn.ru/rics/va/_private/a6/12-23-usacheva.pdf

Usacheva, I.V. 2013a, On the function of "grooved stones". Archaeology, Ethnology and Anthropology of Eurasia, 41(4): 58-64. doi:10.1016/j.aeae.2014.07.007

Usacheva, I.V. 2013b, “Utyuzhki” Evrazii. Nauka, Novosibirsk, 352 p. (in Russian) ("Utyuzhki” of Eurasia)

Usacheva, I.V. 2016, Transverse grooved artefacts from Southwestern Asia and Northern Eurasia: Common traits and the reconstruction of function. Journal of Lithic Studies, 3(3): 589-606. doi:10.2218/jls.v3i3.1653 
Wahida, G. 1981, December, The re-excavation of Zarzi, 1971. Proceedings of the Prehistoric Society, 47: 19-40. doi:10.1017/S0079497X00008847

Weinstein-Evron, M., Yeshurun, R., Kaufman, D., Boarretto, E. \& Eckmeier, E. 2012, New $14 \mathrm{C}$ dates for the Early Natufian of el-Wad Terrace, Mount Carmel, Israel. Radiocarbon, 54(3-4): 813-822. doi:10.1017/s0033822200047469

Wilke, P.J. \& Quintero, L.A. 2009, Getting It Straight: Shaft-Straighteners in a GroovedStone World. In: Modesty and Patience: Studies and Memories in Honour of Nabil Qadi (Abu Salim) (Gebel, H.J.K., Kafafi, Z., \& Ghul, O., Eds.), Yarmouk University, Irbid, Jordan: Monographs of the Faculty of Archaeology and Anthropology Vol. 6, ex Oriente e.V, Berlin: p. 127-134.

Wright, K. 1992, A Classification System for Ground Stone Tools from the Prehistoric Levant. Paléorient, 18(2): 53-81. doi:10.3406/paleo.1992.4573 